\title{
Controlled trial of Pyrogastrone and cimetidine in the treatment of reflux oesophagitis
}

\author{
D G Maxton, J Heald, P J Whorwell, N Y Haboubi
}

\begin{abstract}
Eighty patients with reflux oesophagitis were randomised to receive either Pyrogastrone five tablets daily or cimetidine $\mathbf{4 0 0} \mathbf{~ m g}$ twice daily for six weeks, extended to 12 if necessary. At six weeks, $49 \%$ of the Pyrogastrone treated subjects and $37 \%$ of the cimetidine treated subjects were healed. After 12 weeks the cumulative healing rates were $64 \%$ for Pyrogastrone and $66 \%$ for cimetidine. Compared with baseline both drugs achieved similarly significant improvements in symptom score, endoscopic and histological grading even in those who did not heal completely. Response was not related to length of symptoms or initial severity of oesophagitis. Eleven of $25(44 \%)$ patients healed with Pyrogastrone relapsed within one year compared with 15 of $27(56 \%)$ healed with cimetidine. Although this trend in favour of Pyrogastrone was not significant at one year the early relapse rate was significantly greater in cimetidine treated subjects. At six weeks, five cimetidine treated subjects had relapsed compared with none in the Pyrogastrone group $(p=0.05)$. This study shows that Pyrogastrone and cimetidine are equally effective in the healing of oesophagitis and raises the possibility that Pyrogastrone has marginal benefits in terms of time to relapse.
\end{abstract}

Reflux oesophagitis responds only moderately and unpredictably to medical therapy.' Treatment is often prolonged and response incomplete. Relapse on cessation of treatment is common. ${ }^{23}$ If simple antacids or alginate-antacid mixtures fail to relieve symptoms, $\mathrm{H}_{2}$ antagonists are often prescribed. Carbenoxolone combined with an alginate-antacid, however, has been shown to be effective treatment for reflux oesophagitis. ${ }^{+5} \mathrm{We}$ report a study comparing the efficacy and safety of Pyrogastrone and cimetidine in symptomatic reflux oesophagitis and the subsequent relapse rate.

\section{Methods}

PATIENTS

All patients presented for endoscopy with clinical symptoms suggestive of reflux oesophagitis. Subjects were considered ineligible for the trial if prescribed any gastrointestinal medication other than alginate-antacid or simple antacid mixture in the two weeks before endoscopy or had concomitant gastrointestinal or serious medical pathology. Informed consent was obtained from each subject and the study approved by the Ethical Committee, University Hospital of South Manchester. Patients were then randomised to receive either cimetidine (Smith, Kline and French) $400 \mathrm{mg}$ twice daily or Pyrogastrone (Winthrop) one tablet three times daily and two at night. Each Pyrogastrone tablet contained carbenoxolone sodium $20 \mathrm{mg}$, alginic acid $600 \mathrm{mg}$, dried aluminium hydroxide $240 \mathrm{mg}$, magnesium trisilicate $60 \mathrm{mg}$ and sodium bicarbonate $210 \mathrm{mg}$. Because of the dissimilarity of the tablets, full blinding of the patients would have required a complex double dummy technique and therefore this was not performed.

\section{DESIGN OF STUDY}

After initial endoscopy and clinical assessment, suitable patients were randomised to receive a six week course of either Pyrogastrone or cimetidine. At the end of this period the patient was reendoscoped and, if unhealed, treatment was continued for a further six weeks and clinical and endoscopic assessment repeated. Any patient still unhealed at 12 weeks was withdrawn from the study and deemed a treatment failure.

Patients judged healed at six or 12 weeks were then seen at six weekly intervals for a total of 52

TABLE I Details of symptoms and endoscopic grades

\begin{tabular}{|c|c|}
\hline Symptoms & Grade \\
\hline 0 & Asymptomatic. \\
\hline 1 & $\begin{array}{l}\text { Reflux symptoms and/or minimal heartburn. } \\
\text { Symptoms less than once a week. }\end{array}$ \\
\hline 2 & $\begin{array}{l}\text { Reflux symptoms and/or mild heartburn. More } \\
\text { frequently than once a week. Requires occasional } \\
\text { use of antacids. }\end{array}$ \\
\hline 3 & $\begin{array}{l}\text { Reflux symptoms and/or moderate heartburn. } \\
\text { Symptoms more often than once a day. Requires } \\
\text { frequent antacids. }\end{array}$ \\
\hline 4 & $\begin{array}{l}\text { Reflux symptoms and/or severe heartburn. } \\
\text { Symptoms more often than once a day. Requires } \\
\text { regular antacids. }\end{array}$ \\
\hline 5 & $\begin{array}{l}\text { Reflux symptoms and/or severe heartburn. } \\
\text { Symptoms more often than once a day. Requires } \\
\text { regular antacids. Dysphagia. }\end{array}$ \\
\hline $\begin{array}{l}\text { Endoscopic } \\
0\end{array}$ & $\begin{array}{l}\text { Grade } \\
\text { Normal. }\end{array}$ \\
\hline 1 & $\begin{array}{l}\text { Mild mucosal erythema above gastro-oesophageal } \\
\text { junction. }\end{array}$ \\
\hline 2 & $\begin{array}{l}\text { Mucosal erythema, inflammatory streaks with } \\
\text { contact bleeding not involving entire oesophageal } \\
\text { circumference. }\end{array}$ \\
\hline 3 & $\begin{array}{l}\text { Mucosal erythema and inflammation with bleeding } \\
\text { and slough involving entire oesophageal } \\
\text { circumference. }\end{array}$ \\
\hline 4 & Frank oesophageal ulceration. \\
\hline
\end{tabular}
Dr P J Whorwell, Dept of Medicine, University Hospita of South Manchester, West Didsbury, Manchester

Accepted for publication 6 June 1989

Departments of Medicine
and Pathology,
University Hospital of
South Manchester,
Manchester
D G Maxton
J Heald
P J Whorwell
N Y Haboubi
Correspondence to:
Dr P W Whorwell, Dept of
Medicine, University Hospital
of South Manchester, West
Didsbury, Manchester
M20 8LR.
Accepted for publication
6 June 1989


TABLE II Details of histological scoring system

\begin{tabular}{ll}
\hline Scores & Surface ulceration \\
15 & Present \\
0 & Absent \\
& Basal cell hyperplasia \\
0 & Up to $15 \%$ total epithelial thickness \\
1 & $15-25 \%$ total epithelial thickness \\
2 & $25-50 \%$ total epithelial thickness \\
3 & $>50 \%$ total epithelial thickness \\
& Dermal papillae \\
0 & Up to $66 \%$ of total epithelial thickness \\
1 & Infrequently over $6 \% \%$ of total epithelial thickness \\
2 & Frequently over $66 \%$ of total epithelial thickness \\
& Acute inflammatory infiltrate \\
Epithelium & No polymorphs \\
0 & Mild infiltrate \\
1 & Moderate infiltrate \\
2 & Severe infiltrate \\
3 & Nopolymorphs \\
Lamina propria & \\
0 & Mild infiltrate \\
1 & Moderate infiltrate \\
2 & Severe infiltrate \\
3 &
\end{tabular}

weeks from entering the study. An additional endoscopy was performed when symptoms returned and on all subjects in remission at 52 weeks. Blood pressure, body weight, and adverse reaction monitoring was required at every visit in addition to haematological and biochemical screening while on treatment.

Clinical assessment by overall symptom score was obtained at each attendance. Symptoms were scored from $0-5$, as shown in Table I. Although several endoscopists took part in the study, each patient was routinely re-endoscoped by the same doctor. Oesophagitis was graded macroscopically from $0-4$. Endoscopic definitions are also given in Table I. At each endoscopy, three oesophageal biopsies were obtained from the site of maximal inflammation. Biopsies were assessed 'blind' by an experienced histologist and scored for surface ulceration, basal cell hyperplasia, acute inflammatory infiltrate and presence of high papillae to produce an overall 'surface epithelium' score. Table II details the histological scores. If complete surface ulceration was observed, no other epithelial characteristics were scored.

Healing was defined as a final (six or 12 week) endoscopic score of 0 or 1 with a final symptom score of 2 or less with no symptomatic deterioration over the study period. Relapse was defined as deterioration of symptoms by more than one grade together with an endoscopic score of 1 or greater or an endoscopic grade greater than 2 at 52 weeks. Initial symptoms and endoscopic scores are shown in Table III, and there was no significant difference between either treatment group at initial assessment.

\section{Results}

Ninety four patients were recruited into the study. Forty seven patients received Pyro-

TABLE III Initial symptom and endoscopic grade

\begin{tabular}{llrrrrr}
\hline & Treatment group & 1 & 2 & 3 & 4 & 5 \\
\hline Symptom & Pyrogastrone & 1 & 5 & 11 & 20 & 2 \\
Grade & Cimetidine & 1 & 3 & 8 & 23 & 6 \\
& & 0 & 1 & 2 & 3 & 4 \\
Endoscopic & Pyrogastrone & 0 & 17 & 8 & 6 & 6 \\
Grade & Cimetidine & 7 & 10 & 8 & 6 & 10
\end{tabular}

TABLE IV Overall treatment responses

\begin{tabular}{|c|c|c|c|c|}
\hline & & Pyrogastrone & Cimetidine & Significance \\
\hline 6 weeks & $\begin{array}{l}\text { Healed } \\
\text { Withdrawn } \\
\text { Not healed }\end{array}$ & $\begin{array}{l}19(49 \%) \\
3 \\
17\end{array}$ & $\begin{array}{l}15(37 \%) \\
2 \\
24\end{array}$ & NS \\
\hline 12 weeks & $\begin{array}{l}\text { Healed } \\
\text { Withdrawn }\end{array}$ & $\begin{array}{r}6 \\
0 \\
11\end{array}$ & $\begin{array}{r}12 \\
2 \\
10\end{array}$ & NS \\
\hline $\begin{array}{l}\text { Overall on } \\
\text { treatment }\end{array}$ & $\begin{array}{l}\text { Not healed } \\
\text { Healed } \\
\text { Withdrawn } \\
\text { Not healed }\end{array}$ & $\begin{array}{l}11 \\
25(64 \%) \\
14\end{array}$ & $\begin{array}{l}10 \\
27(66 \%) \\
14\end{array}$ & NS \\
\hline
\end{tabular}

Significance relates to comparisons between treatment groups $(\chi$ : test).

gastrone and 47 cimetidine. Fourteen patients were excluded from the main analysis, eight on Pyrogastrone (four coexistent disease, three selfwithdrawal/non-compliance, one proscribed drug taken) and six on cimetidine (two coexistent disease, three self withdrawal/non-compliance, one proscribed drug taken). There was no significant difference between the groups in age (range 18-75), sex, length of reflux history, alcohol or tobacco consumption.

Thus 80 patients were entered into the analysis, 39 on Pyrogastrone and 41 on cimetidine. The results of acute treatment are shown in Table IV. At six weeks, 19 (49\%) patients receiving Pyrogastrone and $15(37 \%)$ receiving cimetidine were considered healed. After treatment for a further six weeks, another six Pyrogastrone and 12 cimetidine patients healed. Thus overall 25 of 39 patients $(64 \%)$ responded to six or twelve weeks' treatment with Pyrogastrone, while 27 of 41 (66\%) responded to a similar course of cimetidine. There was no significant difference in response between regimens either overall or at any time.

Eleven of 25 patients (44\%) healed with Pyrogastrone relapsed during follow up compared with 15 of $27(56 \%)$ healed by cimetidine (Table V). This trend towards increased relapse with cimetidine did not reach statistical significance. There was a tendency for cimetidine treated patients to relapse earlier and this reached significance $(p=0.05)$ at six weeks with five cimetidine treated but no Pyrogastrone treated patients relapsing at this time (Table V).

Median deterioration in endoscopic grade in those who relapsed was 2 for both the Pyrogastrone and cimetidine groups. Deterioration in symptom scores, however, was 2 for Pyrogastrone and 3 for cimetidine treated patients. Symptom scores are shown in Table VI. Initial symptom scores were similar in both groups. After treatment for six or 12 weeks, 61 of 77

TABLE V Relapse rates

\begin{tabular}{|c|c|c|c|c|}
\hline Time (wks) & & Pyrogastrone & Cimetidine & Significance \\
\hline 6 & $\begin{array}{l}\text { Relapsed } \\
\text { Withdrawn } \\
\text { In remission }\end{array}$ & $\begin{array}{r}0 \\
1 \\
24\end{array}$ & $\begin{array}{r}5 \\
1 \\
21\end{array}$ & $p=0.05$ \\
\hline 12 & $\begin{array}{l}\text { Relapsed } \\
\text { Withdrawn } \\
\text { In remission }\end{array}$ & $\begin{array}{r}2 \\
1 \\
22\end{array}$ & $\begin{array}{r}8 \\
1 \\
18\end{array}$ & NS \\
\hline 24 & $\begin{array}{l}\text { Relapsed } \\
\text { Withdrawn } \\
\text { In remission }\end{array}$ & $\begin{array}{r}6 \\
2 \\
17\end{array}$ & $\begin{array}{r}10 \\
2 \\
15\end{array}$ & NS \\
\hline End of study & $\begin{array}{l}\text { Relapsed } \\
\text { Withdrawn } \\
\text { In remission }\end{array}$ & $\begin{array}{r}11 \\
3 \\
11\end{array}$ & $\begin{array}{r}15 \\
2 \\
10\end{array}$ & NS \\
\hline
\end{tabular}


TABLE VI Changes in symptom, endoscopic and histological grades over the study period

Score $(\mathrm{P}=$ Pyrogastrone. $\mathrm{C}=$ cimetidine $)$

Symptom score

Assessment

Week 6

Overall

(weeks 6 and 12)

Treatment
P
C
P
C

Improved
$24^{\star}$
$29+$
$29+$
$32+$

No change
12
11
7
7

$\begin{array}{ll}\text { Worse } & \begin{array}{l}\text { Median symptom } \\ \text { grade change }\end{array} \\ 2 & -1 \\ 1 & -1 \\ 2 & -1 \\ 0 & -2\end{array}$

Endoscopic score

$\begin{array}{ll}\text { Week 6 } & \text { Treatment } \\ \begin{array}{l}\text { Overall } \\ \text { (weeks 6 and 12) }\end{array} & \text { C } \\ & \text { P }\end{array}$

Improved
$20 \dagger$
$19 \dagger$
$25 \dagger$
$23 \dagger$

No change
15
12
9
6

Worse
1
3
2
3

Median endoscopic grade change

grade
-1

$-1$

-1
-1

Histological score

\begin{tabular}{llllll} 
& Treatment & Improved & No change & Worse & $\begin{array}{l}\text { Median histological } \\
\text { grade change }\end{array}$ \\
Overall & $\mathrm{P}$ & 17 & 11 & 7 & 0 \\
(weeks 6 and 12) & $\mathrm{C}$ & 18 & 16 & 4 & 0 \\
\hline
\end{tabular}

${ }^{\star} \mathrm{p}<0.05$ compared with baseline levels; $\nmid \mathrm{p}<0.001$ compared with baseline levels (McNemar's test).

patients had improved. There was no difference between either therapy, a significant, but similar, improvement over baseline symptom scores being observed.

The results of endoscopic assessment are also shown in Table VI. The majority of patients showed significant improvement over the baseline levels, predominantly in the initial six weeks. Endoscopic scoring and healing was comparable in both treatment groups.

Adequate histological specimens were not available on all patients, however, initially cimetidine treated patients tended to have more surface ulceration. This difference did not reach statistical significance, however, and in all other parameters both groups were comparable. Table VI shows the change in surface epithelium scores after treatment, for those subjects with adequate samples. Seventeen of 35 (49\%) on Pyrogastrone improved compared with 18 of $38(47 \%)$ treated with cimetidine.

Data on length of pre-existing symptoms of oesophagitis was available in 49 patients. In the 22 patients who responded completely to treatment with either drug the average length of preceding history was $47 \cdot 5$ months, while that of the 27 who failed to completely improve was 41.5 months. These figures are not significantly different.

In order to determine whether either treatment was preferable in severe oesophagitis separate analyses were performed on patients with an initial endoscopic grading of 2 or more, those with initial symptom scores of 3 or more, and finally subjects with both. These groups consisted of respectively $44(55 \%), 70(88 \%)$ and $37(46 \%)$ subjects of the 80 analysed.

In all three severe groups both Pyrogastrone and cimetidine produced significant endoscopic and clinical improvement compared to baseline assessment. The improvement was similar with both drugs, however, and therefore neither drug offered a significant advantage over the other.

There were no serious adverse events on either drug. Mean blood pressure, and body weight did not significantly increase over baseline level in either group over the study period. Haematological and biochemical profiles were also per- formed on all patients and showed no significant or consistent change. Specifically in the Pyrogastrone group serum sodium $(140.2 v 141 \cdot 2$ $\mathrm{mmol} / \mathrm{l}$, normal range $132-143 \mathrm{mmol} / \mathrm{l}$ ) and serum potassium $(4.46 v 4.32 \mathrm{mmol} / \mathrm{l}$, normal range $3.5-5.0 \mathrm{mmol} / \mathrm{l})$ were similar before and after treatment respectively. In no case did serum potassium fall below $3.5 \mathrm{mmol} / 1$.

\section{Discussion}

Treatment of oesophagitis remains a difficult and recurrent problem despite the introduction of new anti-ulcer drugs. This study shows that the majority of patients seen after referral to hospital will respond to six weeks' treatment with either cimetidine or Pyrogastrone. An additional smaller number will respond to a further six weeks' treatment. This improvement is independent of severity of endoscopic reflux disease or symptoms. Several studies have shown cimetidine to be more effective for reflux symptoms than placebo, ${ }^{67}$ but endoscopic and histological improvement has not always followed. ${ }^{7}$ Our overall acute response rate of $66 \%$ for cimetidine is similar to other reports, ${ }^{38}$ although less than for peptic ulcer disease. ${ }^{9}$ Pyrogastrone has been less well studied, but is also considered superior to placebo. ${ }^{5}$ An overall response rate of around $70 \%$ was claimed, again comparable to the present study. ${ }^{5}$ Our results also suggest there is little to choose between cimetidine and Pyrogastrone for acute reflux oesophagitis. Both therapies produce similar and significant improvements in symptom score, endoscopic assessment and histological evaluation with around two-thirds of patients responding to either treatment.

Surprisingly, subjects with the shortest symptom history do not respond more favourably than those with chronic problems, but no difference in length of pre-existing symptoms between treatment responders and non-responders was found. Although carbenoxolone, contained in Pyrogastrone, has the reputation for producing oedema, hypertension and hypokalaemia, none of these complications was observed during the trial.

The relapse rates observed in this study after the use of cimetidine are similar to those previously reported in the literature ${ }^{1011}$ and better than those achieved with omeprazole. ${ }^{12}$ The relapse rate after Pyrogastrone healing was significantly less in the short term but by 12 months was only a trend. It is of interest that lower relapse rates have been reported after the healing of peptic ulceration by carbenoxolone and it is possible that a similar mechanism of action may be operative in oesophagitis. ${ }^{13}$ Alternatively, an increased relapse rate may be particularly associated with $\mathrm{H}_{2}$ antagonists. ${ }^{1+}$ The relapsive nature of oesophagitis is a major clinical problem and any drug that confers a lower relapse rate on the disease would naturally lead to less medication having to be consumed and possibly less cost.

In conclusion, Pyrogastrone and cimetidine given for six or 12 weeks are equally effective in reducing both symptomatic and endoscopic measures of oesophageal inflammation. There 
was a significant decrease in early relapse after Pyrogastrone, but a trial on larger numbers of patients would be needed to establish whether the trend observed for decreased relapse after 12 months is maintained and becomes significant.

1 Castell DO. Long term therapy for chronic gastroesophageal reflux. Arch Intern Med 1987; 147: 1701-3.

2 Behar J, Sheahan DG, Biancini P, et al. Medical and surgical management of reflux oesophagitis. N Engl F Med 1975; 293 . 263-8.

3 Liebermann DA. Medical therapy for chronic reflux oesophagitis. Long term follow-up. Arch Intern Med 1987; 147 1717-20.

4 Reed PI, Davies WA. Controlled trial of a carbenoxolone/ alginate antacid combination in reflux oesophagitis. Curr alginate antacid combination

5 Hamill JJ. Management of reflux oesophagitis. Practitioner 1983; 227: 637-9.

6 Powell-Jackson P, Barkley H, Northfield TC. Effect of cimetidine in symptomatic gastro-oesophageal reflux. Lancet 1978; ii: 1068-9.
7 Behar J, Brand DL, Brown FC, et al. Cimetidine in the treatment of symptomatic gastro-oesophageal reflux. Gastroenterology 1978; 74: 441-8.

8 Wesdorp E, Bartelsman J, Pape K, et al. Oral cimetidine in reflux oesophagitis: a double-blind controlled trial. Gastroreflux oesophagitis: a dou
enterology $1978 ; 74: 821-4$.

9 Wormsley KG. Short-term treatment of duodenal ulceration In: Baron, JH, ed. Cimetidine in the 80's. Edinburgh Churchill Livingstone, 1981: 3-8.

10 Bright-Asare P, Behar J, Brand DL, et al. Effect of long-term maintenance cimetidine therapy on gastroesophageal reflux disease. Gastroenterology 1982; 82: 1025.

11 Greaney MG, Irvin TT. Cimetidine for the treatment of symptomatic gastro-oesophageal reflux. $\mathrm{Br} \mathcal{F}$ Clin Pract 1981; 35: 21-4

12 Hetzel DJ, Dent J, Reed W, et al. Healing and relapse of reflux oesophagitis after treatment with omeprazole $20 \mathrm{mg}$ or $40 \mathrm{mg}$ daily [Abstract]. Gut 1987; 28: A 1376-7.

13 Reed PI, Vincent-Brown I, Cook PJ, et al. Comparative study of carbenoxolone and cimetidine in the management of of carbenoxolone and cimetidine in the management
duodenal ulcer. Acta Gastroenterol Belg 1983; 46: 459-68.

14 Dobrilla G, Vallaperta P, Amplatz S. Influence of ulcer healing agents on ulcer relapse after discontinuation of acute treatment: a pooled estimate of controlled clinical trials. Gut 1988; 29: 181-7. 